\title{
Preface to the special issue on seismotectonics of Asia: Progress in seismotectonic studies at Peking University
}

\author{
Yongshun John Chen * \\ Institute of Theoretical and Applied Geophysics, School of Earth and Space Sciences, Peking University
}

Seismotectonics is one of the new research areas of seismology with its main focus on studying the detailed seismic structure of lithosphere and upper mantle using seismic records, particularly the records collected at portable seismic arrays. Development of new seismic methods utilizing seismic arrays such as receiver functions, SKS-splitting analysis, body- and surface-wave tomography, and recently ambient noise tomography (Langston, 1977; Dueker and Sheehan, 1997; Silver and Chan, 1991; Shapiro and Campillo, 2004) have revealed the detailed seismic structure of the world's continents and ocean basins as well. This has provided us with fundamental observations to improve our understanding of the tectonics and mantle deformation at depths at both regional and continental scales.

While networks of permanent seismic stations around the world have provided us with continued high-quality recordings, their fixed distribution in space has limited the resolution of seismic images of the continental lithosphere, particularly in regions with few permanent seismic stations or with no seismic rays passing through. Fortunately, portable seismographs which became available to seismologists since the 1980s have filled in the gap since they could be deployed at almost any place on the continents. Later they could even be deployed at seafloor as ocean bottom seismographs (OBS) with a much higher cost, of course.

Most of the portable seismographs including some of the OBSs now are broadband instruments, which enable seismologists to apply array techniques and new methods such as finite frequency tomography to significantly improve the resolution of seismic images of the lithosphere and upper mantle structures beneath the continents and part of the ocean basins (e.g., Hung et al., 2004).

The continued continental collision process between the Indian and Asian continents has built not only the world's highest mountain belt (the Himalayas) with elevations as high as $8.9 \mathrm{~km}$ (the Mount Everest) but also the world's largest plateau (Tibetan Plateau) with an average elevation of $5 \mathrm{~km}$. The interplay between the continental collision at Tibet and the subduction process of the Pacific and Philippine Sea plates in the western Pacific controls the large-scale tectonics of the East Asia including the destruction of the North China craton.

The complex large-scale tectonics of East Asia has been the focus of seismotectonic studies for the past thirty years. Ever since the first Sino-French seismic array along the Golmod-Lhasa road in the early 1980s a number of portable seismic arrays have been deployed in Tibet and the rest of the Chinese mainland. While most of these field programs in the last century were led by western scientists and used funding from outside of China, an increasing number of field programs conducted in the past 10 years were led by Chinese scientists and funded by agencies within China. With the rapid increase in the number of portable broadband seismographs among various institutions in China, portable seismic arrays have become a regular and effective way to obtain broadband seismic records at boundaries and interiors of important tectonic units of Chinese mainland.

The progress of the seismotectonics program at Peking University is one of the examples of the rapid development in seismotectonics research at several institutions in China. Supported by the Peking University's "985" fund, the first group of 16 portable broadband seismographs imported from abroad arrived at the Institute of Theoretical and Applied Geophysics (ITAG) of the School of Earth and Space Sciences (SESS) at Peking University in December 2004. These 16 seismographs were deployed in southern Tibet in May 2005 as part of the international field program of Hi-CLIMB (Phase II). This is the first time that the faculty and stu- 
dents at Peking University went out to the field and deployed their own seismographs. The success in completing the 14-month long recording in southern Tibet and the subsequent publications at international peer-reviewed journals (Fu et al., 2008; Fu and Chen, 2010; Jin et al., 2009; Jiang et al., 2009; Liang et al., Nabelek et al., 2009; 2008; 2010; Wei et al., 2010) not only officially kicked off the beginning of the seismotectonics program at Peking University but also effectively introduced the program to the international community. With continued support from the Peking University the second group of 24 broadband seismographs was imported in the summer of 2006. They were immediately deployed at the eastern boundary of Odors across the Shanxi graben.

While Peking University has only 40 portable broadband seismographs they have been effectively deployed as small seismic arrays (20 stations) at several important tectonic boundaries of China such as the seismic active fault zones around the Odors block and the northern and northeastern boundary of Tibetan Plateau. Since May 2005 the seismotectonics group at Peking University has collected more than 380 station-years of seismic records and the preliminary results have been reported at international conference such as American Geophysical Union Fall meetings (Zhou et al., 2006; Jin et al., 2006, 2008; Liang et al., 2006, 2007, 2009; Tang et al., 2006; Fu et al., 2006; Chen et al., 2007a, b, 2008; Chen and Jin, 2008; Wei et al., 2008, 2009; Wang et al., 2009; Yue et al., 2009) and national conference such as CGS annual meetings. Since 2008 the seismotectonics group at Peking University has deployed over 100 stations along an east-west linear array from Qingdao at the Sandong peninsula to the Qinghai Lake in northern Tibet. This deployment is part of the North China Craton Seismic Arrays project funded by the Chinese Natural Science Fuundation's new initiative known as the "North China Craton destruction" program. The collective effort by the seismotectonics group at Peking University and groups at other institutions in China will not only provide the Earth science community the important seismic observations of the crust and upper mantle structure beneath the Chinese mainland but also will eventually put Chinese scientists to the leading position in understanding the large-scale tectonics in East Asia.

Finally, as the guest editor of the special issue of "Seismotectonics of Asia", I sincerely thank the authors of the papers included here for their contribution to the "young" scientific journal of Earthquake Science, which has the ambitious plan to become one of the most important journals in earthquake science in Asia. While achieving that objective will be a long and hard uphill battle the enthusiastic support and contributions from Chinese community such as this special issue is the key to shorten and finish that uphill journey. Therefore, I strongly encourage all seismologists and geophysicists to submit your valuable contributions to Earthquake Science, the peer-reviewed English journal in China.

\section{References}

Chen Y J and Jin G (2008). Seismic evidence for the Moho in southern Tibet as a phase change boundary. Eos Trans $A G U$ 89(53), Fall Meet. Suppl., Abstract T11E-07.

Chen Y J, Chen L, Zheng T and Zhou S (2007a). Integrated seismic arrays for imaging the north China Craton: the "Destruction of the North China Craton" project. Eos Trans $A G U$ 88(52), Fall Meet. Suppl., Invited Abstract T22D-04.

Chen Y J, Zhou S, Ning J, Feng Y, Tang Y, Jin G, Fu Y, Sandvol E and Liu M (2007b). Seismic array observations at the boundary of Ordos plateau, North China. Eos Trans $A G U$ 88(52), Fall Meet. Suppl., Abstract T22D-05.

Chen Y J, Zhou S, Ning J, Tang Y, Jin G, Fu Y, Sandvol E and Liu M (2008). Seismic array observations at the boundary of Ordos plateau, North China, invited abstract, SAA 2008 meeting in Santa Fe, April 18, 2008.

Dueker K and Sheehan A (1997). Mantle discontinuity structure from midpoint stacks of converted $\mathrm{P}$ to $\mathrm{S}$ waves across the Yellowstone hotspot track. $J$ Geophys Res 102(B4): 8 3138327.

Fu Y V, Chen Y J, Li A, Zhou S, Liang X, Ye G, Jin G, Jiang M and Ning J (2008). Indian mantle corner flow at southern Tibet revealed by shear wave splitting measurements. Geophys Res Lett 35: L02308, doi: 10.1029/2007GL031753.

Fu Y, Chen Y J, Li A, Zhou S, Ning J, Feng Y, Tang Y, Jin G, Liang X, Jiang M, Sandvol E and Liu M (2007). Strong crust-mantle coupling at Ordos plateau in North China inferred from shear-wave splitting observations of three seismic arrays at its boundary. Eos Trans $A G U$ 88(52), Fall Meet. Suppl., Abstract T22D-02.

Fu Y, Li A and Chen Y J (2010). Crustal and upper mantle structure of Southeast Tibet from Rayleigh wave tomography. $J$ Geophys Res, in press.

Hung S-H, Shen Y and L-Y Chiao (2004). Imaging seismic velocity structure beneath the Iceland hot spot: A finite frequency approach. J Geophys Res 109: 08305.

Jiang M, Zhou S, Tong X, Liang X and Chen Y J (2009). Accurate depth determination of deep earthquake in southern Tibet and its geodynamics implication. Chinese $J$ Geophys 52(9): 2 237-2 244 (in Chinese with English abstract).

Jin G, Chen Y J and Basang C (2009). Investigation of local earthquakes in the Lhasa region. Chinese J Geophys 52(12): 3020-3 026 (in Chinese with English abstract).

Jin G, Chen Y J, Sandvol E, Zhou S-Y, Tang Y-C, Liang X-F, Ye G, 
Wilson D C and Nábelek J (2006). Receiver function images of the crust and upper mantle structure of southern Tibet. Eos Trans AGU 87(52), Fall Meet. Suppl., Abstract T53F-04.

Jin G, Tang Y-C, Zhou S-Y and Chen Y J (2008). Spectra Analysis of the Wenchuan (8.0) Great Earthquake and its aftershocks. Eos Trans $A G U$ 89(53), Fall Meet. Suppl., Abstract U23B-0049.

Langston C A (1977). Corvallis, oregon, crustal and upper mantle receiver structure from teleseismic $\mathrm{P}$-waves and $\mathrm{S}$-waves. Bull Seismol Soc Am 67(3): 713-724.

Liang X, Shen Y, Chen Y J and Ren Y (2010). Crustal and mantle velocity models of southern Tibet from finite frequency tomography. J Geophys Res, in press.

Liang X, Zhou S, Chen Y J, Jin G, Xiao L, Liu P, Fu Y, Tang Y, Lou $X$ and Ning J (2008). Earthquake distribution in southern Tibet and its tectonic implications. $J$ Geophys Res 113: B12409, doi: 10.1029/2007JB005101.

Liang X, Zhou S-Y, Xiao L, Jin G, Liu P, Fu Y-Y, Tang Y-C, Lou X-T, Ning J-Y, Chen Y J and Nábelek J (2006). Joint inversion for earthquake locations and $2 \mathrm{D}$ velocity structure beneath southern Tibet. Eos Trans $A G U$ 87(52), Fall Meet. Suppl., Abstract T53F-01.

Liang X-F, Chen Y J, Sandvol E, Yue H, Hearn T and Ni J (2009). Upper mantle structure of the Eastern Tibetan Plateau from finite frequency body wave tomography. Eos Trans $A G U \mathbf{9 0}$, Fall Meet. Suppl., Abstract T14C-06.

Liang X-F, Shen Y and Chen Y J (2007). Crustal and mantle velocity models of southern Tibet from finite frequency tomography. Eos Trans $A G U$ 88(52), Fall Meet. Suppl., Abstract T23F-06.

Nabelek J, Hetenyi G, Vergne J, Sapkota S, Kafle B, Jiang M, Su H, Chen Y J, Huang B-S and the Hi-CLIMB Team (2009). Underplating in the Himalaya-Tibet collision zone revealed by the Hi-CLIMB experiment. Science 325: 1371-1 374, doi: 10.1126/science. 1167719 .

Shapiro N M and Campillo M (2004). Emergence of broadband Rayleigh waves from correlations of the ambient seismic noise. Geophys Res Lett 31(7), doi: 10.1029/2004GL019491.

Silver P G and Chan W W (1991). Shear wave splitting and sub-continental mantle deformation. $J$ Geophys Res 96: $16429-16454$.

Tang Y, Chen Y J, Yang Y and Ding Z (2009). Ambient noise and surface wave tomography in North China. Eos Trans AGU 90, Fall Meet. Suppl., Abstract T11B-1806.

Tang Y-C, Chen Y J, Sandvol E, Zhou S-Y, Jin G, Fu Y-Y, Liang X-F, Ning J-Y, Feng Y-G, Wang L, Liu M and Wilson D C (2006). Receiver function study of a seismic array across the western Weihe graben, the southern boundary of the Ordos. Eos Trans AGU 87(52), Fall Meet. Suppl., Abstract T54C-08.

Wang H, Chen Y J, Sandvol E, Zhou S, Gai Z, Feng Y, Wang Y, Yue H, Tang Y, Wei S, Fan W, Cao Y, Li P, Wang R, Hearn T and Ni J (2009). Seismic anisotropy of northern Tibet: Combine data from Indepth IV array and permanent stations. Eos Trans $A G U$ 90, Fall Meet. Suppl., Abstract T11B-1803.

Wei S, Chen Y J, Sandvol E, Zhou S, Yue H, Jin G, Hearn T M, Jiang M, Wang H, Fan W, Liu Z, Ge Z, Wang Y and Ni J (2010). Regional earthquakes in northern Tibetan Plateau: Implications for lithospheric strength in Tibet. Geophys Res Lett 37: L19307, doi: 10.1029/2010GL044800.

Wei S, Chen Y J, Yue H, Jin G, Liang X, Zhou S, Ge Z, Feng Y, Wang Y, Tang Y, Wang H, Cao Y, Fan W, Li P, Wang R, Sandvol E, Hearn T and Ni J (2009). Indepth IV passive seismic array: Locating regional earthquakes in northern Tibet. Eos Trans AGU 90, Fall Meet. Suppl., Abstract T11B-1801.

Wei S, Jin G and John Chen Y (2008). Preliminary evidence for the presence of the Hainan plume from shear wave splitting analyses of a temporary seismic array. Eos Trans $A G U$ 89(53), Fall Meet. Suppl., Abstract DI13A-1683.

Yue H, Chen Y J, Zhou S, Feng Y, Wang Y, Ge Z, Tang Y, Wei S, Wang H, Cao Y, Li P, Liang X, Sandvol E, Hearn T and Ni J (2009). Crust and upper mantle characteristic of Northern Tibet: Receiver function and ambient noise tomography results of Indepth IV array. Eos Trans $A G U$ 90, Fall Meet. Suppl., Abstract T11B-1794.

Zhou S-Y, Chen Y J, Liang X, Ye G, Jin G, Ful Y-Y, Tang Y-C, Ning J-Y and Nábelek J (2006). A temporary broadband seismic array in Southern Tibet. Eos Trans $A G U$ 87(52), Fall Meet. Suppl., Abstract T53F-02. 